\title{
陳旧性脳硬塞患者に特ける高比重リポ蛋白質のアポ E
}

\author{
池田裕 清水 映二 前田 次郎 \\ 虎谷 佳幸* 坂本 健一*
}

\begin{abstract}
＜要 約> Mahley らは高比重リポ蛋白質 (以下 HDL) の抗動脈硬化作用には HDL-with apo E が重 要な役割を果していると提唱したが，Bittolo Bon らは心筋硬塞生存者の HDL の apo E (以下 HDL-E) が有意に低濃度であることを示して，この説を臨床面から支持した。ところで陳旧性脳硬塞患者（以下 OCI)の HDL-E についての報告はないよらである。そこで, OCI を対象に免疫固定電気泳動法を応用し て開発した定量法で HDL-E を測定した。対照との比較で，OCI の HDL のコレステロール(以下 HDLC) と apo A-I は低く, apo B, apo B/apo A-I (以下 B/A-I) おょび atherogenic index (以下 A.I.) は高い。そして OCI の HDL-Eは，その濃度も全 apo E に対する比 (以下 HDL-E 比) も, HDL の蛋白 質や脂質に対する相対含量比も対照より有意に低くて, Bittolo Bon らの成績に一致した。 この成績か ら, apo E が異常に減少した HDL ではその抗動脈硬化機能が減弱している可能性が示唆された.さらに 新たな知見として, HDL-E 比と動脈硬化の risk factor の指標とされている B/A-I や A.I.との間に負の 相関関係が, negative-risk factor の指標とされている HDL-C や apo A-I との間に相関関係が認められ た。また，HDL-E 比と apo B との間に負の相関関係をみいだしたことから，HDL-with apo Eが低比 重リポ蛋白質（以下 LDL）レセプターに競合結合する結果，高 LDL 血症を若起するかも知れないとい う危惧は解消した. 以上から, HDL-E 比が臨床的な negative-atherogenic index として有用であること が示唆された。
\end{abstract}

Key words : HDL-E 比, 抗動脈硬化指標, 脳硬塞, HDL-with apo E

\section{1. 緒言}

近年，HDLをapo Eの有無によって分類して機能 を評価する傾向がある. Mahley らによると, HDLwith apo E LDL レセプターに ${ }^{125}$ I-LDL と競合して 結合するが, HDL-without apo E にはその機能がない ことから, HDL のこのような抗動脈硬化的機能には apo E の存在が必要であろらと考完られている。そし てこの説を臨床面から肯定する報告として, Bittolo Bon $ら^{2)}$ は, 心筋硬塞生存者では正脂血にコントロー ルされていても HDL-E は有意に低下していることを 示した。だが脳硬塞患者の HDL-E を測定した報告は ないようである.そこで, OCI 患者の HDL-E を測定し て同年齢層の対照のものと比較し，さらに従来から提 唱されてきた動脈硬化の指標との関連性を検討するこ とで, HDL-Eについて抗動脈硬化的指標としての評

H. Ikeda, E. Shimizu, J. Maeda：和歌山県立医科 大学検査診断学

* Y. Toratani, K. Sakamoto：和歌山労災病院内科 受付日. 1987. 4. 15 .
価をも試みた。

\section{2. 対象}

対象は, 1 年から 8 年前に脳硬塞による入院治療歴 がある, 50 歳から70歳の, 有意な肝臓や腎臓の機能障 害を認めない, インスリンや血糖降下剂で治療中の糖 尿病患者を除いた男性10例と女性10例である。この OCI 群の血清脂質レベルは，コレステロール（以下 Chol)が $250 \mathrm{mg} / \mathrm{d} l$ 以下, トリグリセライド(以下 $\mathrm{TG}$ ) が $150 \mathrm{mg} / \mathrm{d} l$ 以下の正脂血レベルにコントロールされ ていた，同年齢層の正脂血の健康な男性 10 例と女性 10 例を対照群とした。

\section{3. 方 法}

採血は早朝空腹時に执こなって, 得た血清を $7{ }^{\circ} \mathrm{C} に$ 保存して 2 日以内に検查した. Chol と TGは酵素法で 測り, apo A-I, apo B, apo Eは単純免疫拡散法に上 る測定プレート(第一化学)で測った. HDL 分画はリ ンタングステン酸二塩化マグネシゥムによる沈降法に よって分取した. HDL-E は免疫固定電気泳動法を応 
用した HDL-apo E 定量法3)で測定した. A.I.は総 Chol と HDL-C との差を HDL-C で割って求めた。測定結 果は Mean \pm S.D.で表示し, 推計学的処理は Student's t-testによった。

\section{4. 成 績}

1. Apo Eのリポ蛋白質間分布図 (以下 apo $\mathrm{E}$ profile)(図 1)

$\alpha$ リポ蛋白質 (以下 $\alpha \mathrm{LP}$ ) と pre- $\beta$ LP の間に独立 した apo E 分画 (矢印) が HDL-E で, 対照の分画に 比較して OCI の HDL-E 分画は明白に小さい。

2. 対照と OCI の脂質, apo, 動脈硬化指標のレベル の比較 (表 1)

対照のレベルに比較して，OCI の Chol 濃度には差 がないが TG は有意に高く, HDL-C と apo A-I は有 意に低濃度であり, apo B は有意に高濃度であるが apo E 濃度については高い傾向はあっても有意差は認 められなかった.A.I.特よび B/A-I については, OCI の 方が対照よりも有意に高值であった。

3. HDL-E 比の比較 (図 2)

血清 apo $\mathrm{E}$ 濃度中に占める HDL-E の分画比を示す HDL-E 比 (HDL-E $\times 100 /$ total apo E, \%) と HDL-E 濃度は, 対照では $42.1 \pm 6.4 \%$ と $1.4 \pm 0.3 \mathrm{mg} / \mathrm{d} l$ であ
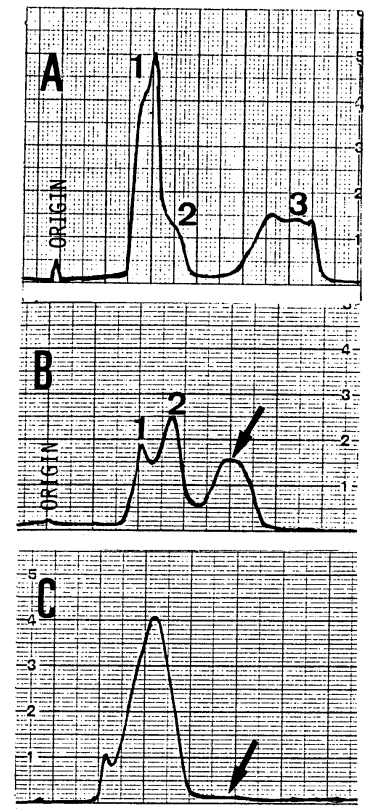

図 1 Apo E profile

デンシトグラフ A はリポ蛋白質電気泳動図で, 1 は $\beta$ リポ蛋白質， 2 は pre- $\beta$ リポ蛋白質， 3 は $\alpha$ リ术蛋白 質. B と C は免疫固定電気泳動後に蛋白染色した apo E profile で, 矢印は HDL-Eの分画を示す，B は対照 から, Cは脳硬塞患者から得た。

表 1 脳硬塞患者の脂質, apo, 動脈硬化的指標

C は対照, OCI は陳旧性脳硬塞患者, ${ }^{*}=\mathrm{p}<0.001$ in comparison with control

\begin{tabular}{|c|c|c|c|c|c|c|c|c|c|}
\hline & no. & $\begin{array}{c}\mathrm{TC} \\
\mathrm{mg} / \mathrm{dl}\end{array}$ & $\begin{array}{c}\mathrm{TG} \\
\mathrm{mg} / \mathrm{dl}\end{array}$ & $\begin{array}{c}\mathrm{HDL}-\mathrm{C} \\
\mathrm{mg} / \mathrm{dl}\end{array}$ & $\begin{array}{l}\mathrm{apo} A-\mathrm{I} \\
\mathrm{mg} / \mathrm{dl}\end{array}$ & $\begin{array}{c}\mathrm{apo} B \\
\mathrm{mg} / \mathrm{dl}\end{array}$ & $\begin{array}{c}\mathrm{apo} \mathrm{E} \\
\mathrm{mg} / \mathrm{dl}\end{array}$ & $\mathrm{A} . \mathrm{I}$. & $\mathrm{B} / \mathrm{A}-\mathrm{I}$ \\
\hline OCI & 20 & $\begin{array}{c}195 \\
\pm 24\end{array}$ & $\begin{array}{c}116^{*} \\
\pm 27\end{array}$ & $\begin{array}{c}31^{*} \\
\pm 7\end{array}$ & $\begin{array}{l}106^{*} \\
\pm 10\end{array}$ & $\begin{array}{l}115^{*} \\
\pm 15\end{array}$ & $\begin{array}{c}4.0 \\
\pm 0.8\end{array}$ & $\begin{array}{c}5.2 * \\
\pm 1.2\end{array}$ & $\begin{array}{c}1.09 * \\
\pm 0.14\end{array}$ \\
\hline C & 20 & $\begin{array}{c}190 \\
\pm 24\end{array}$ & $\begin{array}{c}80 \\
\pm 20\end{array}$ & $\begin{array}{c}49 \\
\pm 6\end{array}$ & $\begin{array}{c}135 \\
\pm 11\end{array}$ & $\begin{array}{c}85 \\
\pm 17\end{array}$ & $\begin{array}{c}3.5 \\
\pm 0.6\end{array}$ & $\begin{array}{c}2.6 \\
\pm 0.6\end{array}$ & $\begin{array}{c}0.63 \\
\pm 0.11\end{array}$ \\
\hline
\end{tabular}

$\frac{H D L-E}{\text { apo E }} \quad H D L-E \quad \frac{H D L-E}{\text { apo A-I }} \quad \frac{H D L-E}{H D L-C}$
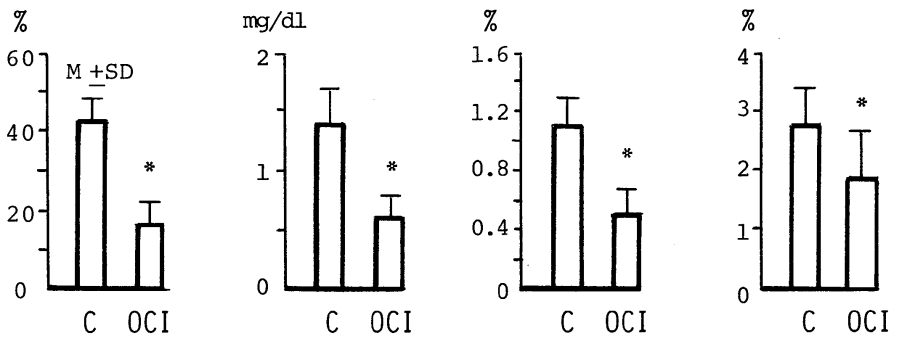

図 2 脳硬塞患者の HDL-E

C は対照, OCI は陳旧性脳硬塞患者, ${ }^{*}=\mathrm{p}<0.001$ in comparison with control 


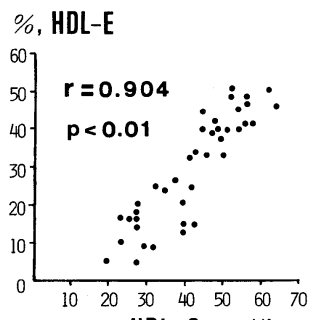

HDL-C $\mathrm{mg} / \mathrm{dl}$

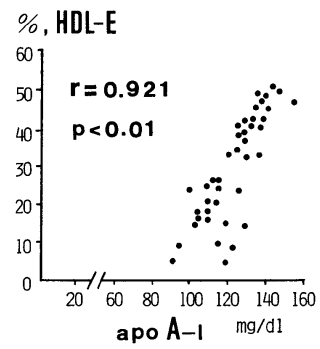

図 3 HDL-E 比と HDL-C の相関図（左）と HDL-E 比と apo A-I の相関図（右）

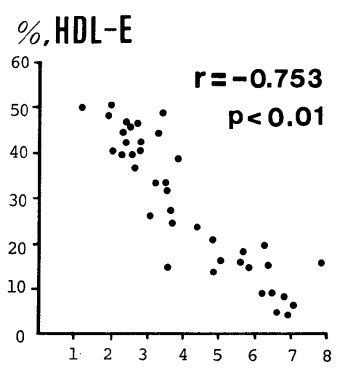

A.I.

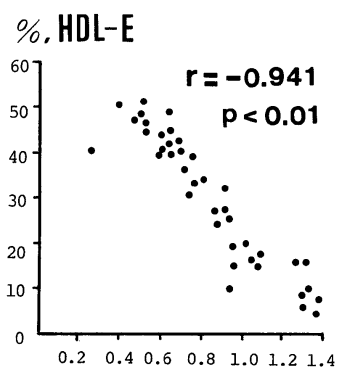

$B / A-1$
図 4 HDL-E 比と A.I.の相関図 (左) と HDL-E 比と B/A-I の相関図（右）

るのに対して, OCI では $16.8 \pm 7.2 \%$ と $0.6 \pm 0.2 \mathrm{mg} /$ $\mathrm{d} l$ で，有意に低い．また，HDL-E と apo A-I の比(以 下 HDL-E/A-I, \%) と, HDL-E と HDL-C の比 (以下 HDL-E/HDL-C, \%) についても同様の有意差を認め た.

4. HDL-E 比と HDL-C 濃度の相関性, および HDL-E 比と apo A-I 濃度の相関性（図 3)

OCI 20例と対照20例の群に打いて, HDL-E 比と HDL-C との間に, および HDL-E 比と apo A-I との間 に有意な相関関係が認められた。

5. HDL-E 比と A.I.の相関性, および HDL-E 比と B/A-I との相関性（図 4)

HDL-E 比と A.I.との間に，および HDL-E 比と B/ A-I との間に有意な負の相関関係が認められた。

6. HDL-E 比と apo B 濃度の相関性 (図 5 )

HDL-E 比と apo B との間に有意な負の相関関係が 認められた。

\section{5. 考 察}

動脈硬化と高脂血症の関連性は古くから言及されて きたが, Goldstein and Brown の LDL-pathway 説4)以

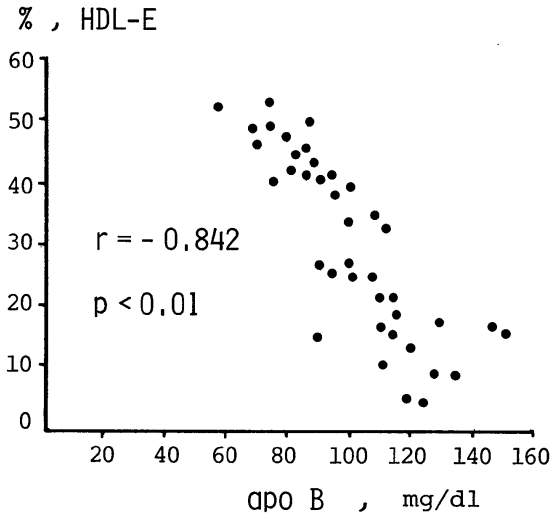

図 5 HDL-E 比と apo B の相関図

来, apo B 含有リポ蛋白質 (chylomicron, 超低比重リ ポ蛋白質, 中間比重リポ蛋白質, LDL) が動脈硬化の risk factor として認識されている5 ${ }^{5) 6}$. 一方, Miller and Miller ${ }^{7}$ が HDL と動脈硬化を基盤とした虚血性 心疾患の発生との間に負相関関係がみられることか ら, HDL が抗動脈硬化的機能を有する可能性を提唱 してからは, HDLを negative-risk factor として評価 した研究が数多く報告されてきた ${ }^{8)}$. そして Mahley らは, 典型的な HDL である HDL-without apo Eが末 梢細胞膜から Chol を受けとり，LCAT の働きでこれ をエステル化して粒子内に移動させる際に apo Eを 受けとって HDL-with apoE となるが，その大部分は 肝蔵の apo E, apo B， Eレセプターに取り込まれて 代謝され, Chol は胆汁酸として排泄され帛，また一方で は HDL-with apo Eが LDLレセプター (apo B， Eレ セプター）に対してLDLと競合して結合するとい $5^{1)}$. そこで, HDLの抗動脈硬化作用としての, 末梢 組織から Chol を肝臓へ reverse cholesterol transportする役割と，末梢細胞に招ける LDLレセプター への LDL 取り込みを抑制する役割に関して，HDLwith apo Eの重要性が認識されるようになった。しか しながら, HDL-Eを測定するに際して, 超遠心分離操

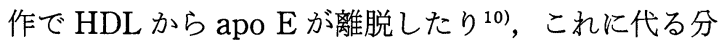
離法としてのゲル濾過クロマトグラフでは多数検体処 理が困難だし，希釈された検体の apo E 定量には RIA 法を導入せざるを得ないなどの事情もあるため，実際 に動脈硬化性疾患を対象として HDL-E を測定した臨 床研究は僅かしかない、はじめて, 動脈硬化を基盤と 乙て発症すると考学られる心筋硬塞の生存者の HDL-E が，1984年に Bittolo Bon ら²)によって報告さ 
れたが，彼らは沈降法によって上清として分離した HDL の apo Eをロケット免疫電気泳動で定量してい る.

著者らが用いた測定法，つまり，抗 apo E 抗血清を 用いた免疫固定電気泳動で得た apo E profile（図 1) では, apo Eは apo B 含有リポ蛋白質に分布する他 に，これらと HDL-without apo Eである $\alpha$ LP との 間に独立して存在した(矢印)。これが HDL-Eであり， デンシトメトリーして得たその分画比に血清 apo E 濃度を乗じて HDL-E 濃度として計算する訳だが，こ の定量法についての再現性や濃度希釈に抢ける直線性 などは, 臨床検査法として満足できるものであっだ².

この研究の対象は, 脳硬塞の明白な症候と生化学的 検査所見や CT 所見を呈した既応がある，50歳から70 歳の高年齢層の男性10例と女性10例であるが，全例有 意な肝臓腎臓機能障害は認めない。㐬た，糖尿病患者 では周知のごとく carbohydrate-induced hypertriglyceridemia を呈して mid band が高頻度に出現した $\eta^{11)}$, 脂質・apo 代謝障害が合併するので, 食事療法で コントロールしきれない例は除外してある。また，脂 質レベルは，特に男性例では Chol が正常域でも TG が高值であったが, Chol は2 $50 \mathrm{mg} / \mathrm{d} l$, TG は $150 \mathrm{mg} /$ $\mathrm{d} l$ 以下の群に限定した。この OCI 群の脂質や apo $レ$ ベルを調べた結果は, 動脈硬化性疾患患者を対象とし た諸家の研究業績255) 8)12) 14) と同様の成績であり,つ まり対照のレベルに比較して OCI では正脂血にコン トロールされていても, HDL-C と apo A-I が有意に低 くて, apo B や B/A-I 执よび A.I.が有意に高レベルで あった。 そして OCIの HDL-Eは, その濃度も分画比 も, さらには HDL の蛋白質量や脂質量に対する相対 含量比を意味する HDL-E/A-I や HDL-E/HDL-C も 対照よりも有意に低レベルであった。この成績は，正 脂血陳旧性心筋硬塞患者を対象とした Bittolo Bon ら の成績と一致するものである，この知見は，冠動脈と 脳動脈の区別なく，動脈硬化を基盤とする硬塞群には HDL への apo E 分布障害が存在する事実を明白にし たものである。そして， apo E が異常に減少している HDL では，その抗動脈硬化作用が減弱している可能 性を示唆するものでもあり, Bittolo Bonの研究と同 様に, Mahley らの説を臨床的に肯定するものである う.さらに, 本研究の新たな知見として, 高脂血症の 際にも, 高 TG 血症に伴う血清 apo $\mathrm{E}$ 濃度の上昇 ${ }^{13)}$ の 影響を受けない HDL-E 比と, 前述の諸家の業績から 動脈硬化の risk factor の指標と考えられている apo
B，B/A-I，A.I.との間に負の相関がみいだされ，また， negative-risk factor の指標とされている HDL-Cや apo A-I との間には正の相関関係がみいだされた。さ らに, HDL-with apo E が優先的に LDL レセプターに 競合結合するために生理的な LDL 代謝が抑制されて 高 LDL 血症を若起しかねない，いいか方ると HDLwith apo E が動脈硬化促進の方向に働くのではない かといら危惧は, LDLの主要構成 apoでレセプター を認識する apo B 濃度と HDL-E 比との間に負の相関 関係が証明されたことから解消するだろう.以上から， HDL-E 比は臨床的な negative-atherogenic index と して有用と評価されるだろうと考察した。

ただし，HDL-E 比は有意の肝障害を反映して増大 し, HDL-C と負相関するし ${ }^{15)}$, 甲状腺機能異常症では

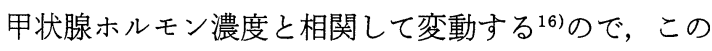
ような合併症を有する例での臨床判断には注意しなけ ればならない。また, 動脈硬化性疾患で HDL-E 比が減 少する理由について言及するためには, LPL 欠損症に 拈ける HDL への apo E 分布欠如に近い減少の報告 ${ }^{17)}$ や，デキストラン硫酸静注や人工透析治療後の LPL 活性賦活時に HDL-E 比が増大した著者らの経験 ${ }^{18)}$ 手掛かりに，今後の検討をなたねばならない。

\section{6. 結 論}

1. OCI の HDL-Eはその濃度も分画比も, 対照より も有意に低い。

2. HDL-E 比は動脈硬化の risk factor の指標であ る B/A-Iや A.I.と負の密な相関を, negative-risk factor の指標である HDL-C や apo A-I と密な相関を呈 する。

3. HDL-E比と apo B との間に負の相関関係がみ いだされたことから, HDL-with apo E が高 LDL 血症 を惹起するとは考觉がたい。

以上の知見から, HDL-E 比は臨床的な negativeatherogenic index として期待できるだろう。

\section{文献}

1) Mahley RW, Innerarity TL: Interaction of canine and swine lipoproteins with the low density lipoprotein receptor of fibroblasts as correlated with heparin/manganese precipitability. J Biol Chem 252 : 3980-3986, 1977.

2) Bon Bittolo G, Cazzolato G, Saccardi M,Kostner GM, Avogaro P : Total plasma apo E and 
high density lipoprotein apo $\mathrm{E}$ in survivors of myocardial infarction. Atherosclerosis 53 : 69-75, 1984.

3）池田 裕：免疫固定電気泳動法を応用した HDLapo E定量法. 臨床検查 $30: 1139-1142,1986$.

4) Goldstein JL, Brown MS: The LDL pathway in human fibroblasts: A receptor-mediated mechanism for the regulation of cholesterol metabolism. Current Topics Cellular Regulation $11:$ 147-181, 1976.

5) Goldstein JL, Schrott HG, Harrard WR, Bierman EL, Motulsky AG: Hyperlipidemia in coronary heart disease. J Clin Invest $52: 1533$ -1577, 1973.

6) Bierman EL, Eisenberg S, Stein O, Stein Y : Very low density lipoprotein remnant particles: Uptake by aortic smooth muscle in culture. Biochim Biophys Acta 329: 163-169, 1973.

7) Miller GJ, Miller NE: Plasma-high-densitylipoprotein concentration and the development of ischemic heart-disease. Lancet I : 16-19, 1975.

8) Gordon T, Castelli WP, Hjortland MC, Kannel WB, Dawber TR: High density lipoprotein as a protective factor against coronary heart disease: The Framingham Study. Am J Med 62 : 707-714, 1977.

9) Mahley RW: Atherogenic hyperlipidemia. Med Clin N Amer 66:375-402, 1982.

10) Mackie A, Caslake MJ, Packard CJ, Shepherd $\mathrm{J}$ : Concentration and distribution of human plasma apolipoprotein E. Clin Chim Acta 116 : $35-45,1981$.

11）池田 裕：糖尿病における Mid-bandの出現につ いての考察. 医療 $31: 37-45,1977$.

12) Whayne TF, Alaopovic P, Curry MD, Lee ET, Anderson PS, Schechter E: Plasma apolipoprotein B and VLDL-, and LDL-, and HDLcholesterol as risk factors in the development of coronary artery disease in male patients examined by angiography. Atherosclerosis 39 : 411-424, 1981.

13) Tan MH, Weldon KL, Albers JJ, Cheung MC, Havel RJ, Vigne JL: Serum HDL-cholesterol, apo A-I and apo E levels in patients with abnormal coronary arteries. Clin Invest Med 3 : 225-232, 1980.

14）篠宮正樹, 斉藤 康, 吉田 尚, 山下道隆, 大島仁 士：冠動脈撮影による狭窄所見とアポ蛋白. Ther Res 3:439-442, 1985.

15）池田 裕, 前田次郎：急性肝炎患者に打ける $\alpha_{2}$ apo E. 肝臓 投稿中.

16）池田裕：甲状腺機能と $\alpha_{2}$-アポ蛋白 $\mathrm{E}$ の関連 性. 衛生検査 $35: 1631-1635,1986$.

17）山田信博, 村勢敏郎, 赤沼安夫, 小坂樹徳, 吳東 進, 佐久間真樹：ゲル濾過法による血漿アポ $\mathrm{E} の$ 分析. 動脈硬化 $10: 965-966,1982$.

18) Ikeda H, Maeda J: The specificity and the clinical significance of the profile of the apolipoprotein $\mathrm{E}$, determined by quantitative immunofixation electrophoresis. Jap J Med 25 : 405, 1986. 
Abstract

\title{
Apolipoprotein E in High-Density Lipoprotein in Patients with Old Cerebral Infarction
}

\author{
Hiroshi Ikeda*, Eiji Shimizu*, Jiro Maeda*, \\ Yoshiyuki Toratani** and Kenichi Sakamoto**
}

Mahley et al had proposed that HDL-with apo E would play important roles in protective or anti-atherosclerotic functions of HDL, that is, in reverse cholesterol transporting to liver from peripheral tissues and in competing with LDL for binding to LDL-receptors. And Bittolo Bon et al. in 1984 reported for the first time that apo E concentration in HDL in survivors of myocardial infarction was significantly lower than that in controls. But apo $\mathrm{E}$ in HDL (HDL-E) in patients with old cerebral infarction (OCI) as the atherosclerotic subjects was not yet determined. So, in order to estimate whether HDL-E could be clinically expected to be one of the antiatherogenic index, HDL-E in OCI was determined in this study by Ikeda's method using quantitative immunofixation electrophoresis, by which HDL-E was detected for the first time at near the $\alpha_{2}$-globulin region behind $\alpha$ lipoprotein (that is, HDL-without apo E). Samples were sera acquired in fasting from normolipidemic, aged 5070 years old, 10 male and 10 female OCI without hepatobiliary disorders and age-matched healthy controls, and were examined as to triglycedies, cholesterol, apo A-I, apo B and apo E, in addition to determination of HDL-E. Cholesterol in HDL (HDL-C) and apo A-I were lower, and apo $\mathrm{B}$, apo $\mathrm{B} /$ apo $\mathrm{A}-\mathrm{I}$ ratio $(\mathrm{B} / \mathrm{A}-\mathrm{I})$ and atherogenic index (A.I.) [(cholesterol - HDL-C)/HDL-C]

* Department of Laboratory Medicine, Wakayama Medical College

** Department of Internal Medicine, Wakayama-Rosai Hospital were significantly higher in OCI than in controls. No significant difference in serum levels of apo $\mathrm{E}$ between two groups was observed, but HDL-E concentrations $(0.6$ \pm 0.2 vs $1.4 \pm 0.3 \mathrm{mg} / \mathrm{dl}, \mathrm{p}<0.001$ ), HDL-E ratios (HDL-E $\times 100$ /serum apo $\mathrm{E}, \%)(16.8 \pm 7.2$ vs $42.1 \pm 6.4 \%$, $\mathrm{p}<0.001)$, ratios of HDL-E/apo A-I $(0.5 \pm 0.2$ vs $1.1 \pm$ $0.2 \%, \mathrm{p}<0.001)$ and ratios of HDL-E/HDL-C $(1.9 \pm 0.7$ vs $2.8 \pm 0.6 \%, \mathrm{p}<0.001)$ were significantly lower in OCI than in controls. Therefore, this result would reveal the disturbance of distribution of apo $\mathrm{E}$ to HDL in atherosclerotic subjects as OCI. In other words, it would be suggested from this result that anti-atherosclerotic functions of HDL in which apo E abnormally decreased would be weakened, as well as Bittolo Bon's speculation. And, as new information the significant reverse correlation between HDL-E ratios and levels of apo B which was main apolipoprotein of LDL was recognized in this study, so the information would clear the suspicion that HDL-with apo $\mathrm{E}$ might induce to be atherogenic hyperlow-density lipoproteinemia because of competing with LDL for natural binding to receptors. And more, HDL-E ratios significantly correlated with negative-atherogenic parameters of HDL-C and apo A-I, and inversely correlated with atherogenic parameters of B/A-I and A.I.. The results in this paper suggest that HDL-E ratio would be able to be evaluated as a negative-atherogenic index.

key words: $H D L-E$ ratio, negative-atherogenic index, $H D L$-with apo $E$, cerebral infarction

(Jpn J Geriat 24: 561-566, 1987) 